\title{
KECERDASAN EMOSIONAL BERPENGARUH TERHADAP MOTIVASI BELAJAR MURID
}

\section{EMOTIONAL INTELLIGENCE EFFECT ON STUDENT LEARNING MOTIVATION}

\author{
A Aniyatin'1a dan A Mahrudin 1 \\ 1 Program Studi Manajemen Pendidikan Islam, Fakultas Keguruan dan Ilmu Pendidikan, \\ Universitas Djuanda Bogor, Jl. Tol Ciawi No. 1 Kotak Pos 35 Ciawi Bogor 16720 \\ a Korespondensi: Atin Aniyatin, Email: atin.aniyatin@unida.ac.id \\ (Diterima: 07-02-2017; Ditelaah: 08-02-2017; Disetujui: 21-04-2017)
}

\begin{abstract}
Every student have the different abilities, factor the influence motivation student learning that is internal factor, external factor, and approach to learning. Internal factors the level of intelligence, attitude and motivation students. However the reality not all students have motivation good study, one cause that of student not able to manage emotional well. With emotional intelligence student can control his emotions including motivation the learn. This research approach a quantitative and type of associative research in the of causation. The population in this study that all senior high school Amaliah academic year 2016/2017 which totaling to 94 students, the sample used as many as 64 students. Making data retrived used is a Likert scale questionnaire, observation, interview and documentation. The research shows the regression equation is $\mathrm{Y}=32,4 \%+0,776 \mathrm{X}$ can be said relationship between emotional intelligence and motivation learning a proportional relationship. The coefficient of determination $0,5952=0,354$, the value of the students learning motivation by $35,4 \%$ influenced by emotional intelligence, while $64,6 \%$ the rest influenced by stimulating factor, learning, study method, maxurity, and intelligence.
\end{abstract}

Keywords: emotional intelligence, motivation to learn, student.

\begin{abstract}
ABSTRAK
Setiap murid memiliki kemampuan yang berbeda-beda, faktor yang mempengaruhi belajar murid yaitu faktor internal, eksternal, dan pendekatan belajar. Faktor internal diantaranya tingkat kecerdasan, sikap, dan motivasi murid. Namun kenyataannya tidak semua murid memiliki motivasi belajar yang baik, salah satu penyebabnya yaitu murid tidak mampu mengelola emosi secara baik. Dengan kecerdasan emosional murid akan dapat mengendalikan emosinya termasuk memotivasi diri untuk belajar. Penelitian ini menggunakan pendekatan penelitian kuantitatif, jenis penelitian asosiatif berupa sebab akibat. Populasi yang digunakan yaitu seluruh murid SMA Amaliah tahun ajaran 2016/2017 yang berjumlah 94 murid, sampel yang digunakan yaitu sebanyak 64 murid. Teknik pengambilan data: angket skala likert, observasi, wawancara dan dokumentasi. Hasil penelitian menunjukan persamaan regresi yaitu $Y=32,4 \%+0,776 \mathrm{X}$ dapat dikatakan hubungan bahwa antara kecerdasan emosional dan motivasi belajar murid merupakan hubungan yang berbanding lurus, artinya Koefisien determinasi yaitu $0,5952=0,354$, dengan demikian nilai motivasi belajar murid sebesar $35,4 \%$ dipengaruhi oleh kecerdasan emosional, sedangkan 64,6\% sisanya dipengaruhi oleh faktor stimuli belajar, metode belajar, kematangan, dan kecerdasan murid.
\end{abstract}

Kata kunci: kecerdasan emosional, motivasi belajar, murid. 
Aniyatin A dan A Mahrudin. 2017. Kecerdasan emosional berpengaruh terhadap motivasi belajar murid. Tadbir Muwahhid 1(1): 71-80.

\section{PENDAHULUAN}

Setiap murid mempunyai kemampuan yang berbeda-beda, dapat dikelompokkan pada murid yang berkemampuan tinggi, sedang, bahkan rendah atau gagal. Dalam hal ini, seorang guru yang kompeten diharapkan mampu mengantisipasi kemungkinankemungkinan munculnya kelompok murid yang berkemampuan rendah tersebut dengan cara berusaha mengetahui dan mengatasi faktor yang menghambat proses belajar murid (Syah 2013) karena sosok guru sebagai pendidik yang menentukan proses pembelajaran yang optimal. Walaupun pada zaman sekarang ada banyak sumber belajar alternatif yang tersedia di setiap lembaga pendidikan, seperti LKS, majalah, bahkan internet, tetapi sosok seorang guru tetap menjadi kunci dalam mengoptimalkan sumber belajar yang telah tersedia.

Secara global, faktor-faktor yang berpengaruh dalam belajar murid yaitu faktor internal, eksternal, dan pendekatan belajar. Faktor internal meliputi aspek fisiologis dan psikologis. Aspek psikologis yaitu kualitas belajar murid di antaranya tingkat kecerdasan dan motivasi belajar murid (Syah 2013). Motivasi secara sederhana merupakan pendorong suatu usaha yang disadari untuk mempengaruhi seseorang untuk bertindak melakukan sesuatu dalam mencapai suatu tujuan (Purwanto 2011).

Bila dihubungkan dengan pembelajaran murid motivasi diartikan sebagai pendorong bagi murid untuk melakukan kegiatan pembelajaran baik di lingkungan sekolah maupun di lingkungan keluarga serta lingkungan masyarakat.

Motivasi dibedakan menjadi dua yaitu motivasi intrinsik, dan ekstrinsik. Motivasi yang lebih berperan penting bagi murid adalah motivasi intrinsik, karena lebih konsisten dan tidak tergantung pada pengaruh orang lain (Syah 2013). Murid berbakat adalah murid yang memiliki prestasi gemilang dan lebih unggul dibandingkan dengan murid lainnya. Faktor lain yang turut menentukan perkembangan potensi murid menjadi bakat, yakni kecerdasan emosional (Uno dan Kuadrat 2010).

Murid yang kontrol emosinya baik akan lebih mampu untuk mengembangkan bakat yang dimiliki. Daniel Goleman mengatakan "IQ setinggi-tingginya hanya berperan sekitar 20\% bagi faktor yang menyumbang sukses hidup maka $80 \%$ diisi oleh kemampuan lain" (Goleman 2002).

Namun kenyataannya selama ini Intelligence Quotient (IQ) selalu dianggap sebagai faktor penentu keberhasilan belajar murid. Orang tua dan guru lebih terfokus pada upaya peningkatan intelektualitas semata. Sementara Emotional Quotient (EQ) tidak dikembangkan (Uno dan Kuadrat 2010). Keberhasilan belajar murid hanya dilihat dari tinggi rendahnya nilai akademis saja, tanpa mementingkan sikap sosial dan emosionalnya, akibatnya murid memiliki prestasi belajar yang baik tetapi tidak dapat mengelola emosinya, seperti murid mudah marah-marah, sombong, cemas, depresi dan nakal atau agresif. Maka dengan adanya kecerdasan emosional yang baik dalam diri murid, dengan sendirinya murid akan memiliki keterampilan membawa diri dalam 
berbagai situasi dan kondisi dimana saja murid tersebut berada, termasuk memotivasi diri untuk melakukan pembelajaran.

Berdasarkan data awal yang diperoleh di SMA Amaliah menunjukkan fenomena bahwa masih terdapat sebanyak 22\% murid bermasalah dalam kehadiran, dengan rincian data 7 dari 26 murid kelas X, 10 dari 39 murid kelas XI, dan 4 dari 30 murid kelas XII telah lebih dari 10 kali tidak masuk sekolah dalam satu semester terakhir. Dari data tersebut menunjukkan bahwa motivasi belajar murid SMA Amaliah masih rendah. Mengenai kecerdasan emosional murid di SMA Amaliah dengan indikator penilaian kemampuan bersosial atau membina hubungan yaitu terdapat sebanyak 44\% murid memiliki hubungan sosial yang sangat baik, dengan rincian data: 23 dari 26 murid kelas X, 4 dari 38 murid kelas XI, dan 15 dari 30 murid kelas XII. Dengan demikian masih terdapat $66 \%$ murid yang harus ditingkatkan lagi kemampuan bersosialisasinya.

\section{MATERI DAN METODE}

\section{Materi}

Motivasi atau "Motif” yaitu segala upaya yang mengarahkan seseorang untuk bertindak melakukan sesuatu. Dalam KBBI Motivasi adalah dorongan yang muncul dari diri suatu individu yang mengarahkan pada tujuan tertentu, sementara belajar merupakan proses yang dilakukan murid guna mendapat perubahan sikap baru yang lebih baik secara keseluruhan, yang mana perilaku baru tersebut merupakan hasil dari interaksi dengan lingkungannya (Slameto 2013). Maka dengan adanya motivasi, murid akan melakukan tindakan menuju tercapainya tujuan.
Motivasi merupakan suatu kondisi yang terbentuk dari berbagai tenaga pendorong berupa desakan, motif, kebutuhan dan keinginan. Pendorong tersebut sering disebut dengan istilah motif yang dikategorikan atas motif dasar dan motif sosial. Motif dasar berkenaan dengan segala macam bentuk dorongan untuk memenuhi kebutuhan dasar, bersifat instink dan dimiliki individu sejak lahir. Sedangkan motif sosial adalah perkembangan dari motif dasar yang berkembang karena belajar dan pengalaman yang disadari serta disengaja.

Berdasarkan pengertian tersebut dapat disimpulkan bahwa motivasi belajar yaitu daya dorong murid dalam melakukan kegiatan belajar guna menambah pengetahuan, keterampilan serta pengalaman. Motivasi tersebut ada karena keinginan untuk dapat memahami sesuatu yang mendorong minat belajar murid sehingga sungguh-sungguh dalam belajar dan termotivasi untuk mendapatkan hasil belajar yang baik.

Islam memerintahkan umatnya untuk senantiasa belajar. Al-Quran menyeru manusia agar menggunakan akal pikiran dan segenap potensi yang dimilikinya untuk memperhatikan segala ciptaan Allah SWT. Selain itu Allah SWT memberikan keistimewaan kepada nabi Adam dan memerintahkan malaikat untuk sujud kepada nabi Adam, adalah karena kesiapan nabi Adam untuk belajar dan keberhasilannya untuk mendapatkan ilmu yang diberikan Allah SWT kepadanya yang tidak didapatkan oleh para Malaikat. Sebagaimana dalam Al-Quran surat AlBaqarah ayat 31, yang artinya :

"Dan Dia mengajarkan kepada Adam namanama (benda-benda) seluruhnya, kemudian mengemukakannya kepada para Malaikat lalu berfirman: "Sebutkanlah kepada-Ku nama benda-benda itu jika kamu memang 
benar orang-orang yang benar" (Departemen Agama RI 2013)

Analisisnya, maka dengan belajar Nabi Adam menjadi tinggi derajatnya di atas Malaikat. Hal ini mempunyai arti yang sangat tinggi bagi para tokoh pendidikan, yakni adanya keutamaan yang diberikan Alquran kepada ulama dan sifat-sifat khusus ulama adalah sebagai bukti bahwa belajar mempunyai tempat yang tertinggi dan istimewa. Belajar adalah perantara untuk mengetahui Allah SWT. Belajar juga sebagai jalan untuk mengetahui potensi alam sehingga mampu mempergunakannya untuk kemaslahatan manusia.

Motivasi memiliki fungsi yang sangat penting bagi murid karena seorang murid tentu tidak mungkin melakukan kegiatan pembelajaran tanpa adanya motivasi atau dorongan untuk melakukan suatu kegiatan belajar. Motivasi belajar turut mempengaruhi sejauh mana keberhasilan yang dapat dicapai murid dalam proses pembelajaran.

Faktor yang dapat mempengaruhi hasil belajar murid menurut Ngalim Purwanto yaitu: Kematangan, kecerdasan, latihan, ulangan, motivasi, sifat-sifat pribadi seseorang, kondisi keluarga, dan cara mengajar guru, serta lingkungan dan kesempatan (Purwanto 2011). Belajar bukanlah hasil namun merupakan suatu proses, di dalam proses pembelajaran di kelas murid sebagai raw input memiliki karakteristik yang berbeda baik fisiologi maupun psikologis. Mengenai fisiologi meliputi bagaimana keadaan fisik, panca indera, dan sebagainya. Sedangkan mengenai psikologis adalah minat, bakat, motivasi, tingkat kecerdasan, dan sebagainya. Selain itu, faktor stimuli belajar, faktor metode belajar, dan faktor individual juga dapat mempengaruhi bagaimana proses dan hasil belajar murid (Soemanto 2012).
Motivasi dibedakan atas motivasi intrinsik dan ekstrinsik. Motivasi intrinsik adalah murid melakukan pembelajaran berdasarkan dorongan dan kebutuhan yang secara mutlak behubungan dengan aktivitas belajar, misalnya belajar karena ingin memecahkan suatu permasalahan atau ingin menjadi seorang yang ahli dalam pengetahuan tertentu (Yamin 2013). Sedangkan motivasi ekstrinsik yaitu dorongan yang terjadi di luar diri murid untuk melakukan sesuatu, termasuk belajar, motivasi ini tumbuh oleh dorongan seperti orang tua, guru dan sebagainya. Baik motivasi intrinsik maupun ekstrinsik memiliki peranan penting terhadap kegiatan belajar murid. Meskipun motivasi intrinsik lebih berdampak bagi murid, tetapi bukan berarti motivasi intrinsik dapat berdiri sendiri tanpa dukungan dari luar yang dapat mendorong murid untuk belajar.

Fungsi motivasi dalam kegiatan belajar yaitu sebagai motor penggerak atau pendorong kegiatan pembelajaran, memperjelas tujuan pembelajaran, menyeleksi arah perbuatan, peran motivasi internal dan eksternal dalam pembelajaran, menentukan ketekunan dalam pembelajaran, serta melahirkan prestasi (Iskandar 2012).

Dapat disimpulkan bahwa Motivasi belajar adalah dorongan untuk melakukan kegiatan belajar. Motivasi belajar tersebut dapat terlihat ketika proses belajar berlangsung di kelas, yaitu:

1. disiplin;

2. aktif dalam proses belajar;

3. merasa senang ketika belajar;

4. mengerjakan tugas yang diberikan;

5. menunjukan kegigihan atau semangat dalam belajar. 


\section{Kecerdasan Emosional}

Kecerdasan atau intelegensi dalam psikologi terdiri atas tiga komponen yaitu: kemampuan manusia untuk mengarahkan pikiran atau tindakannya, mengubah arah tindakan apabila telah dilaksanakan, dan mengubah diri sendiri (Uno 2012). Sedangkan emosi bisa diartikan sebagai perasaan yang disertai dengan perubahan perilaku seperti perasaan gembira yang ditunjukan dengan melonjak kegirangan (Hartinah 2010). Reaksi emosi lain yaitu seperti rasa takut, cinta, sedih, rasa ingin tahu dan penasaran.

Kecerdasan emosional dapat diartikan sebagai kemampuan murid untuk dapat memahami dan mengenali perasaan yang sedang dialami dirinya sendiri dan temannya secara efektif. Selain itu murid mampu mengendalikan emosi dengan bijak sehingga dapat memelihara hubungan baik dengan teman dan guru di sekolah.

Tokoh pencipta istilah "Kecerdasan Emosi" adalah Peter Salovey dan Jhon Mayer. Kemudian dikaji secara mendalam oleh Daniel Goleman melalui berbagai riset yang dilakukannya. Salovey menetapkan kecerdasan pribadi sebagai dasar kecerdasan emosional yang dicetuskannya. Salovey membagi kecerdasan emosional kedalam lima wilayah utama sekaligus merupakan aspek atau ciri kecerdasan emosional yaitu: kesadaran diri, pengaturan diri, memotivasi diri sendiri, empati, membina hubungan (Goleman 2002).

Murid yang memiliki kemampuan mengenali perasaannya dapat melakukan pengambilan keputusan-keputusan pribadi dengan bijak. Murid yang mempunyai kemampuan mengelola emosinya akan mampu untuk dapat menguasai serta mengontrol perasaan marah, kecewa, tersinggung dan sedih. Selain itu murid yang mampu menata emosi dan memotivasi diri untuk berkreasi, sehingga lebih produktif dalam segala hal yang ditekuni.

Kecerdasan emosional juga meliputi kemampuan berempati yaitu kecenderungan untuk bisa turut merasakan situasi yang dialami oleh orang lain, dan keterampilan membina hubungan, yaitu keterampilan yang menunjang keberhasilan antar pribadi, murid dengan kecerdasan sosial yang tinggi akan dapat menjalin hubungan pertemanan dengan baik, mampu memimpin, mengorganisasi dan pintar menengahi perselisihan serta memberikan solusi. Mereka adalah jenis yang disukai oleh orang lain, karena secara emosional mereka menyenangkan. Dengan demikian murid akan mampu mengenali dan mengendalikan emosi dirinya dan orang lain yang ada disekitarnya serta diterima di lingkungan sekolah.

Termasuk dalam hal ini murid akan mampu mengetahui emosinya sendiri dan emosi teman-teman atau gurunya di sekolah. Dengan demikian murid yang memiliki keterampilan emosional, akan mampu mengendalikan gejala-gejala emosi yang timbul pada dirinya, baik ketika di kelas, sekolah dan rumah. Pada saat murid tersebut memiliki masalah dalam belajar seperti rasa malas, bosan dan jenuh dalam belajar atau ada hal lain yang membuatnya kesal, sedih, marah dan lain sebagainya, murid akan mampu mengendalikan emosi-emosi tersebut sehingga kegiatan belajar tidak terganggu.

Dalam Islam kajian mengenai emosi bukanlah hal yang baru. Al-Quran dan Hadits banyak menyinggung mengenai emosi. Emosi mendapat posisi penting dalam ajaran Islam sebagai elemen dasar qalbu manusia. Karena itu kata kunci utama kecerdasan emosional di dalam Al-Quran dapat ditelusuri dengan kata kunci qalbu (kalbu) 
dan dengan istilah-istilah lain seperti nafs (jiwa) dan istilah lainnya. Islam bertujuan untuk menciptakan keseimbangan, sehingga setiap individu harus selalu berada dalam kondisi tenang dan merasa cukup dengan dirinya.

Dalam pandangan Islam emosi merupakan karunia Allah SWT yang memiliki berbagai manfaat bagi kelangsungan hidup manusia, kecerdasan emosional dapat diukur dari kemampuan mengendalikan emosi dan menahan diri, dalam Islam disebut dengan istilah sabar. Orang yang paling sabar adalah orang yang paling tinggi kecerdasan emosionalnya. Orang tersebut biasanya sabar dalam menghadapi kesulitan.

Kecerdasan emosional merupakan kecakapan utama, suatu kemampuan yang dapat mempengaruhi kemampuan lainnya, baik berpengaruh memperlancar ataupun menghambat. Goleman mengemukan bahwa orang yang secara emosional cakap, mengetahui dan menangani perasaan mereka dengan baik, dan mampu menghadapi perasaan orang lain dengan efektif, memiliki keuntungan dalam setiap bidang kehidupan. Orang yang memiliki kecakapan emosional yang berkembang akan berpeluang besar untuk bisa bahagia dan berhasil dalam kehidupan, serta mendorong produktivitas mereka. Sebaliknya, orang yang tidak dapat mengendalikan emosionalnya akan mengalami pertarungan batin yang dapat menggangu konsentrasi mereka dalam mengerjakan sesuatu serta dalam proses berpikir.

Dapat disimpulkan bahwa kecerdasan emosional adalah kemampuan murid untuk:

1. dapat menyadari apa yang harus dilakukan, memahami dan mengenali perasaan yang sedang dialami dirinya sendiri dan orang lain secara efektif.
2. murid mampu mengendalikan emosi dan mengekspresikannya dengan tepat,

3. mampu untuk menguasai dan mengontrol perasaan marah, kecewa, tersinggung dan sedih,

4. mampu mengelola perasaan, peka terhadap perasaan orang lain, dan

5. dapat menyesuaikan diri dengan lingkungan dan dapat memelihara hubungan baik dengan orang disekitarnya dan menyelesaikan konflik

\section{Metode}

\section{Metode Penelitian}

Pendekatan penelitian menggunakan pendekatan penelitian kuantitatif, yaitu pendekatan yang digunakan untuk meneliti permasalahan yang sudah jelas, data dapat diamati dan dapat diukur, peneliti bermaksud menguji hipotesis dan generalisasi (Supardi 2012). Penelitian ini memiliki tujuan untuk mengetahui pengaruh variable X (Tingkat Kecerdasan Emosional) terhadap variabel Y (Motivasi Belajar Murid).

Jenis penelitian asosiatif, yaitu mencari hubungan antar dua variabel atau lebih, hubungan ini berupa sebab akibat atau kausal (Iskandar 2013). Teknik analisis yang digunakan yaitu regresi sederhana.

Populasi adalah jumlah keseluruhan dari objek maupun subjek yang memiliki sifat tertentu yang telah ditentukan oleh peneliti untuk diteliti dan selanjutnya disimpulkan (Sujarweni 2014). Dengan menggunakan rumus Yamane Taro, maka diperoleh sampel sebanyak 64 murid dari 94 murid SMA Amaliah dengan derajat kesalahan 7\% $(0,07)$. Penelitian ini dilaksanakan di SMA Amaliah yang beralamat di Jalan Raya Tol Ciawi No.1 Desa Ciawi, Kecamatan Ciawi, Kabupaten Bogor, Provinsi Jawa Barat. 
Teknik pengumpulan data antara lain: Skala likert, observasi, wawancara, dan dokumentasi. Untuk mengetahui kecerdasan emosional serta motivasi belajar murid, peneliti menggunakan skala likert, sedangkan teknik observasi, wawancara dan dokumentasi hanya digunakan untuk menambahkan data-data penelitian.

Sebelum digunakan pada responden penelitian yang sebenarnya, instrumen penelitian diuji coba terlebih dahulu, dengan uji validitas dan reliabilitas. Uji validitas menunjukan apakah suatu instrumen dapat mengukur apa yang hendak diukur (Siregar 2013). Sementara itu, reliabilitas instrumen berkaitan dengan masalah adanya kepercayaan terhadap alat instrumen, ketepatan instrumen serta keajegan atau konsistensi hasil pengukuran (Bisri dan Ichsan 2015).

Uji validitas yang digunakan yaitu teknik korelasi product moment, dengan rumus sebagai berikut.

$r_{x y}=\frac{n \cdot \sum x y-\sum x \sum y}{\sqrt{\left[n \sum x^{2}-\left(\sum x\right)^{2}\right]\left[n \sum y^{2}\left(\sum y\right)^{2}\right]}}$

Keterangan: $r_{x y}=$ koefesien korelasi antara variabel $\mathrm{X}$ dan $\mathrm{Y} ; \mathrm{N}$ = banyaknya peserta tes; $\mathrm{X}=$ skor total; $\mathrm{Y}=$ skor pertanyaan.

Cara menguji reliabilitas untuk keseluruhan item adalah dengan mengoreksi angka korelasi yang diperoleh dengan memasukannya ke dalam rumus alpha cronbanch. Rumus dapat dilihat sebagai berikut.

Rumus: $\mathrm{a}=\boldsymbol{\alpha}=\frac{k}{k-1}\left(1-\frac{\sum S^{2} j}{S^{2} x}\right)$

Keterangan: $\alpha=$ koefisien reliabilitas alpha; $\mathrm{k}=$ jumlah item; $\mathrm{Sj}$ = varians responden untuk item $\mathrm{I}$; $\mathrm{Sx}=$ jumlah varians skor total.

\section{Teknik Pengumpulan Data}

\section{Skala Likert}

Dalam penelitian ini untuk mengukur kecerdasan emosional (variabel $\mathrm{X}$ ) dan motivasi belajar (variabel Y) murid SMA Amaliah peneliti menggunakan jenis angket skala likert. Angket bertujuan untuk memperoleh data mengenai variabel yang akan diteliti, dengan cara menyusun seperangkat pertanyaan secara logis dan sistematis. Skala likert digunakan untuk mengukur sikap, pendapat dan persepsi seseorang maupun persepsi kelompok mengenai fenomena sosial tertentu. Dengan skala likert maka variabel yang hendak diukur telah dijabarkan menjadi indikator variabel. Kemudian indikator tersebut dijadikan sebagai acuan untuk menyusun instrumen yang berupa pertanyaan atau pernyataan.

\section{Observasi}

Observasi adalah pengamatan serta pencatatan yang dilakukan peneliti secara sistematis terhadap gejala-gejala yang terlihat pada objek penelitian. Dalam penelitian ini peneliti melakukan penelitian langsung terhadap murid di SMA Amaliah.

\section{Wawancara}

Wawancara merupakan suatu instrumen yang digunakan peneliti untuk mendapatkan data dan informasi secara lisan. Wawancara hendaknya dilaksanakan secara mendalam guna mendapatkan informasi yang jelas dan valid. Wawancara dalam penelitian ini yaitu peneliti melakukan wawancara kepada kepala sekolah untuk memperoleh informasi guna melengkapi data yang dibutuhkan dalam penelitian ini.

\section{Dokumentasi}

Dokumentasi yaitu mengumpulkan data dengan melihat atau mencatat suatu laporan 
yang sudah tersedia. Metode ini dilakukan dengan melihat dokumen-dokumen resmi seperti catatan-catatan dan buku-buku peraturan yang ada. Dalam penelitian ini metode dokumentasi digunakan untuk memperoleh data mengenai jumlah murid di SMA Amaliah, jumlah guru di SMA Amaliah, serta data awal mengenai kecerdasan emosional dan motivasi belajar murid di SMA Amaliah.

\section{Teknik Analisis Data}

Data analisis deskrptif menggunakan tabel distribusi frekuensi yaitu data diurutkan dalam bentuk kelompok baris berdasarkan kelas-kelas interval (Supardi, 2013). Analisis deskriptif dibutuhkan untuk menggambarkan data tingkat kecerdasan emosional dan motivasi belajar murid SMA Amaliah Ciawi-Bogor.

\section{Uji Prasyarat Analisis}

Uji prasyarat yang digunakan adalah Uji normalitas, yaitu dilakukan guna mengetahui data berdistribusi normal atau tidak dengan cara menggunakan rumus chikuadrat, selanjutnya uji linieritas dengan uji kelinieran regresi.

\section{Analisis Inferensial}

Analisis inferensial yang dilakukan dalam penelitian ini yaitu: Korelasi Product Moment (Pearson), Persamaan Regresi, Signifikansi Persamaan Regresi (Uji F), dan koefesien determinasi. Korelasi Product Moment dilakukan untuk mengetahui ada tidaknya hubungan antara kecerdasan emosional dan motivasi belajar, dengan menggunakan rumus sebagai berikut.

$$
r_{x y}=\frac{n \cdot \sum x y-\sum x \sum y}{\sqrt{\left[n \sum x^{2}-\left(\sum x\right)^{2}\right]\left[n \sum y^{2}\left(\sum y\right)^{2}\right]}}
$$

Keterangan: $\mathrm{r}_{\mathrm{xy}}=$ koefesien korelasi antara variabel $\mathrm{X}$ dan $\mathrm{Y} ; \mathrm{N}$ = banyaknya peserta tes; $\mathrm{X}$ = skor kecerdasan emosional; $\mathrm{Y}=$ skor motivasi belajar.

Selanjutnya, untuk melihat pengaruh tingkat kecerdasan emosional terhadap motivasi belajar murid digunakan rumus regresi sederhana, sebagai berikut:

$$
\begin{gathered}
\hat{\mathrm{Y}}=a+b X \\
b=\frac{n \sum X Y-\sum X \sum Y}{n \sum X^{2}-\left(\sum X\right)^{2}} \\
a=\bar{Y}-b \bar{X}
\end{gathered}
$$

Keterangan: Y : variabel dependen; X : variabel independen; $\mathrm{a}$ : konstanta (harga $\mathrm{Y}$ untuk $\mathrm{X}=0$ ); $\mathrm{b}$ : angka arah atau koefisian regresi. Yang menunjukan angka peningkatan maupun penurunan variabel dependen yang didasarkan pada perubahan variabel independen. Bila b (+) maka arah regresi naik, dan arah regresi turun apabila b (-).

Untuk menguji signifikansi koefisien regresi dengan uji $\mathrm{F}$ menggunakan rumus, sebagai berikut.

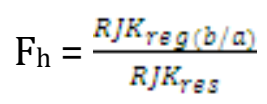

Keterangan: $F_{h}$ : F hitung; RJKreg(b/a): rata-rata jumlah kuadrat regresi b/a; RJKres : rata-rata kuadrat garis residu.

Selanjutya mencari nilai koefisien determinasi, nilai koefisien determinasi dinyatakan dalam kuadrat dari nilai koefisien korelasi $\mathrm{r} 2 \mathrm{x} 100 \%=\mathrm{n} \%$, bermakna bahwa nilai variabel dependent dapat dipengaruhi oleh variabel independent sebesar n\%, sedangkan sisanya sebesar (100-n) \% dipengaruhi oleh variabel lain (Supardi 2013).

\section{HASIL DAN PEMBAHASAN}

\section{Hasil}

\section{Uji Prasyarat Analisis}

Uji prasyarat yang digunakan adalah Uji normalitas, yaitu dilakukan guna mengetahui data berdistribusi normal atau tidak dengan cara menggunakan rumus chi- 
kuadrat, selanjutnya uji linieritas dengan uji kelinieran regresi.

\section{Analisis Inferensial}

Analisis inferensial yang dilakukan dalam penelitian ini yaitu: Korelasi Product Moment (Pearson), Persamaan Regresi, Signifikansi Persamaan Regresi (Uji F), dan koefesien determinasi. Korelasi Product Moment dilakukan untuk mengetahui ada tidaknya hubungan antara kecerdasan emosional dan motivasi belajar, dengan menggunakan rumus:

$$
r_{x y}=\frac{n \cdot \sum x y-\sum x \sum y}{\sqrt{\left[n \sum x^{2}-\left(\sum x\right)^{2}\right]\left[n \sum y^{2}\left(\sum y\right)^{2}\right]}}
$$

Keterangan: $\mathrm{r}_{\mathrm{xy}}=$ koefesien korelasi antara variabel $\mathrm{X}$ dan Y; N = banyaknya peserta tes; $\mathrm{X}$ = skor kecerdasan emosional; $\mathrm{Y}=$ skor motivasi belajar.

Selanjutnya untuk melihat pengaruh tingkat kecerdasan emosional terhadap motivasi belajar murid digunakan rumus regresi sederhana, sebagai berikut.

$$
\begin{gathered}
\hat{\mathrm{Y}}=a+b X \\
b=\frac{n \sum X Y-\sum X \sum Y}{n \sum X^{2}-\left(\sum X\right)^{2}} \\
a=\bar{Y}-b \bar{X}
\end{gathered}
$$

Keterangan: Y : variabel dependen; X : variabel independen; $\mathrm{a}$ : konstanta (harga $\mathrm{Y}$ untuk $\mathrm{X}=0$ ); $\mathrm{b}$ : angka arah atau koefisian regresi. Yang menunjukan angka peningkatan maupun penurunan variabel dependen yang didasarkan pada perubahan variabel independen. Bila b (+) maka arah regresi naik, dan arah regresi turun apabila b (-).

Untuk menguji signifikansi koefisien regresi dengan uji $\mathrm{F}$ menggunakan rumus, sebagai berikut.

$$
\mathrm{F}_{\mathrm{h}}=\frac{\text { RJK }_{\text {Yeg }}(\mathrm{b}(\mathrm{a})}{\text { RJK }_{\mathrm{Y}}}
$$

Keterangan: $F_{h}$ : F hitung; RJKreg(b/a) : rata-rata jumlah kuadrat regresi b/a; RJKres : rata-rata kuadrat garis residu.

Selanjutya mencari nilai koefisien determinasi, nilai koefisien determinasi dinyatakan dalam kuadrat dari nilai koefisien korelasi $\mathrm{r} 2 \times 100 \%=\mathrm{n} \%$, bermakna bahwa nilai variabel dependent dapat dipengaruhi oleh variabel independent sebesar $\mathrm{n} \%$, sedangkan sisanya sebesar (100-n) \% dipengaruhi oleh variabel lain (Supardi 2013).

\section{KESIMPULAN DAN IMPLIKASI}

\section{Kesimpulan}

Berdasarkan hasil penelitian mengenai "Kecerdasan Emosional berpengaruh Terhadap Motivasi Belajar Murid", maka dapat disimpulkan bahwa hubungan antara kecerdasan emosional dengan motivasi belajar merupakan hubungan yang berbanding lurus.

Berdasarkan uji regresi sederhana diperoleh nilai konstanta (a) 32,678 dan nilai konstanta (b) 0,776 maka $\hat{Y}=32,678+$ 0,776X karena nilai koefisien (b) bertanda positif 0,776 dapat dikatakan semakin tinggi kecerdasan emosional, maka motivasi belajar murid akan semakin tinggi juga. Adapun jumlah dalam setiap tingkatan ketika ditambah yaitu sebesar 0,776. Selanjutnya diperoleh nilai $F_{\text {hitung }} 34,065$ dan $F_{\text {tabel }}$ dengan $\mathrm{df}_{\text {reg }}=1 \mathrm{df}_{\text {res }}=62$ adalah 4,00 pada taraf $5 \%$. Dengan demikian Fhitung $(34,065)>F_{\text {tabel }}(4,00)$ sehingga $\mathrm{H}_{0}$ ditolak, dan disimpulkan terdapat pengaruh yang signifikan kecerdasan emosional terhadap motivasi belajar.

Koefisien determinasi yaitu $0,595^{2}=$ 0,354 . Dengan demikian nilai motivasi belajar murid sebesar 35,4\% dipengaruhi oleh kecerdasan emosional, sedangkan 64,6\% motivasi belajar murid dipengaruhi oleh faktor stimuli belajar, metode belajar, kematangan, dan kecerdasan murid.

\section{Implikasi}

Kecerdasan emosional memiliki pengaruh terhadap motivasi belajar murid, maka dari itu hendaknya para pendidik lebih 
memperhatikan dan meningkatkan kecerdasan emosional murid serta melibatkan keseimbangan emosi murid dalam proses pembelajaran guna meningkatkan motivasi murid untuk melakukan kegiatan pembelajaran.

Sekolah dapat menerapkan kebijakankebijakan guna meningkatkan motivasi belajar murid, salah satunya lebih memperhatikan perkembangan emosional murid. Kecerdasan emosional berpengaruh terhadap motivasi belajar murid. Oleh karena itu, masalah penelitian ini hanya yang berhubungan dengan masalah kecerdasan emosional dan motivasi belajar murid. masalah yang dapat diteliti lebih lanjut faktor stimuli belajar, metode belajar, kematangan, dan kecerdasan terhadap motivasi belajar murid.

\section{DAFTAR PUSTAKA}

Bisri H dan M Ichsan. 2015. Penilaian otentik dengan teknik nontes di sekolah Dasar. Jurnal Sosial Humaniora. Volume 6 Nomor 2.

Departemen Agama RI. 2013. Al-Quran dan terjemahnya. Cetakan Kesepuluh. Diponegoro, Bandung.

Goleman D. 2002. Kecerdasan emosional. Terjemahan: T Hermaya. Cetakan Ke-12. Gramedia Pustaka Utama, Jakarta.
Hartinah S. 2010. Pengembangan peserta didik. Cetakan Kedua. Refika Aditama, Bandung.

Iskandar. 2012. Psikologi pendidikan sebuah orientasi baru. Cetakan Ketiga. Rosda Karya, Bandung.

Iskandar. 2013. Metodologi penelitian pendidikan dan sosial. Cetakan Kelima. Referensi, Jakarta.

Purwanto MN. 2011. Psikologi pendidikan. Remaja Rosdakarya, Bandung.

Siregar S. 2013. Statistik parametrik untuk penelitian kuantitatif. Bumi Aksara, Jakarta.

Slameto. 2013. Belajar dan faktor-faktor yang mempengaruhi. Rineka Cipta, Jakarta.

Soemanto W. 2012. Psikologi pendidikan: landasan kerja pemimpin pendidikan. Rineka Cipta, Jakarta.

Sujarweni W. 2014. Metodologi penelitian. Pustaka Baru Press, Yogyakarta.

Supardi. 2012. Aplikasi statistika dalam penelitian. Ufuk Press, Jakarta.

Syah M. 2013. Psikologi pendidikan dengan pendekatan baru. Cetakan Ke-18. Remaja Rosdakarya, Bandung.

Uno H. 2012. Orientasi baru dalam psikologi pembelajaran. Cetakan Kelima. Bumi Aksara, Jakarta.

Uno HB dan M Kuadrat. 2010. Mengelola kecerdasan dalam pembelajaran. Bumi Aksara, Jakarta.

Yamin M. 2013. Kiat membelajarkan siswa. Referensi, Jakarta. 